\title{
MERINTANGI PENGUBURAN JENAZAH COVID-19 DITINJAU BERDASARKAN PASAL 178 KITAB UNDANG-UNDANG HUKUM PIDANA
}

\author{
Oleh : Muhammad Rezky Rinaldy ${ }^{1}$ dan Syamsudin ${ }^{2}$
}

${ }^{1}$ Fakultas Hukum Universitas 17 Agustus 1945 Samarinda

${ }^{2}$ Dosen Fakultas Hukum Universitas 17 Agustus 1945 Samarinda

\begin{abstract}
Indonesia and even the world now feel the impact of the Corona virus outbreak (covid-19), in connection with it hindering the burial of the bodies of victims who died. The phenomenon of corpse rejection of corona virus patients (covid-19) continues to occur in various regions. In fact, the body must be buried immediately no later than 4 hours after being declared dead. The main reason people are reluctant to accept the bodies of patients co-19 because of fear of contracting. While the medical ensure that the body will not transmit the virus. The body in the coffin has been wrapped and declared sterile. The type of research used in this study is the type of normative legal research, which is a legal research method that uses a statutory approach

The results of the study showed that obstructing officers who will carry out official burials could indeed be convicted. Law enforcement officials can use Article 178 of the Criminal Code. not a complaint offense. Law enforcement officials can immediately take action without anyone complaining. "If the incident fulfills the elements contained in Article 178 of the Criminal Code, the perpetrators can be charged. However, it must look at intentions and actions as a condition for imposing a crime on someone.
\end{abstract}

\section{Keywords : Covid-19, Merintagi, Bodies}

\begin{abstract}
ABSTRAK
Indonesia bahkan dunia sekarang merasaskan dampak dari wabah virus Corona (covid-19), kaitnnya dengan hal merintangi pemakaman jenasah korban yang meninggal. Fenomena penolakan jenazah pasien virus corona (covid-19) terus terjadi di berbagai daerah. Padahal, jenazah tersebut harus segera dimakamkan paling lambat 4 jam setelah dinyatakan meninggal dunia. Alasan utama masyarakat enggan menerima
\end{abstract}


jenazah pasien covid-19 karena khawatir tertular. Sedangkan para medis memastikan jenazah tersebut tidak akan menularkan virus. Jenazah di dalam peti sudah dibungkus dan dinyatakan steril.

Jenis penelitian yang digunakan pada penelitian ini adalah-jenis penelitian hukum normatif, yaitu suatu metode penelitian hukum yang menggunakan pendekatan perundang-undangan

Hasil penelitian menunjukan bahwa menghalang-halangi petugas yang akan melakukan pemakaman resmi secara hukum memang dapat dipidana. Aparat penegak hukum dapat menggunakan Pasal 178 KUHP. Meskipun demikian legalitas pasal ini adalah delik biasa, bukan delik aduan. Aparat penegak hukum dapat langsung melakukan tindakan tanpa ada yang mengadu. "Jika kejadiannya memenuhi unsur-unsur yang ada dalam Pasal 178 KUHP, maka pelaku bisa saja dijerat. Tetapi, tetapi harus melihat pada niat dan perbuatan sebagai syarat untuk menjatuhkan pidana kepada seseorang.

Kata Kunci : Covid-19, Merintangi, Jenazah

\section{PENDAHULUAN}

\section{A. Latar Belakang}

Tiga komponen demografi yang mempengaruhi struktur penduduk adalah kematian atau mortalitas. Tinggi rendahnya tingkat kematian penduduk di suatu daerah akan berpengaruh pada pertumbuhan penduduk. Mati merupakan peristiwa hilangnya semua tanda-tanda kehidupan secara permanen, yang bisa terjadi setiap saat setelah kelahiran hidup. Definisi tersebut menjelaskan bahwa keadaan mati hanya bisa terjadi jika sudah terjadi kelahiran hidup, dengan demikian keadaan mati selalu didahului oleh keadaan hidup, atau dengan kata lain, mati tidak pernah ada jika tidak ada kehidupan, sedangkan hidup selalu diawali dengan lahir hidup (live birth). Pengurusan jenazah hukumnya fardhu kifayah, dan anjuran Rasulullah dalam hal ini adalah menyegerakannya. Namun, kadangkala pada praktiknya muncul beberapa masalah karena berkenaan dengan, misalnya kepentingan studi, penyelidikan hukum, atau adat, dan dapat pula terjadi karena ada faktor wabah virus yang menjadi faktor penghambat dalam pelaksanaan penguburan jenazah.

Setiap manusia akan mengalami sebuah proses kehidupan yang dimulai dari kelahiran hingga kematian." Demikianlah, manusia pasti

Arifin, Y. N. 2016. Optimalisasi Usaha Penyediaan Lahan Pemakaman dalam Kawasan Perumahan di Kabupaten Boyolali. Jurnal Geografi Volume 13 No.1, 80. 
akan sampai pada akhir kehidupannya, kematian akan menyapa semua manusia tanpa terkecuali. Hal ini telah dijelaskan dalam firman Allah SWT dalam Q.S. Al- "Ankabuut (29) : 57. "Setiap yang bernyawa akan merasakan mati. Kemudian hanya kepada kami kamu dikembalikan." Indonesia bahkan dunia sekarang merasaskan dampak dari wabah virus Corona (covid-19), kaitnnya dengan hal merintangi pemakaman jenasah korban yang meninggal. Fenomena penolakan jenazah pasien virus corona (covid-19) terus terjadi di berbagai daerah. Padahal, jenazah tersebut harus segera dimakamkan paling lambat 4 jam setelah dinyatakan meninggal dunia. Alasan utama masyarakat enggan menerima jenazah pasien covid19 karena khawatir tertular. Sedangkan para medis memastikan jenazah tersebut tidak akan menularkan virus. Jenazah di dalam peti sudah dibungkus dan dinyatakan steril. ${ }^{2} \quad$ Sanksi pidana yang dimaksud adalah Pasal 178 Kitab Undang-Undang Hukum Pidana jo. Pasal 3 Peraturan Mahkamah Agung Nomor 2 Tahun 2012 tentang Penyesuaian Batasan Tindak Pidana Ringan dan Jumlah Denda dalam KUHP yang berbunyi, "Barang siapa dengan sengaja merintangi atau menghalanghalangi jalan masuk atau pengangkutan mayat ke kuburan yang diizinkan, diancam dengan pidana penjara paling lama satu bulan dua minggu atau pidana denda paling banyak satu juta delapan ratus ribu rupiah." Ketentuan pada pasal 178 KUHP.

\section{B. Rumusan Masalah}

Bagaimana tinjauan hukum terhadap tindak pidana merintangi penguburan jenazah Covid-19 berdasarkan pasal 178 Kitab UndangUndang Hukum Pidana dan Faktor apa saja yang menyebabkan terjadinya perintangan penguburan jenazah Covid-19?

\section{KERANGKA DASAR TEORI}

\section{A. Pengertian Hukum Pidana}

"Menurut Simons hukum pidana itu dapat dibagi menjadi hukum pidana dalam arti objektif atau strafrecht in objectieve zin dan hukum pidana dalam arti subjektif atau strafrecht in subjectieve zin. Hukum pidana dalam arti objektif adalah hukum pidana yang berlaku, atau yang juga disebut sebagai hukum positif atau ius poniale".

\footnotetext{
2 https://www.jurnaljambi.co/2020/04/13/pasca-penolakan-jenazah-perawat-wargasewakul-khawatir-tak-dapat-pelayanan-kesehatan/ diakses tanggal 26 April 2020
} 
Simons merumuskan hukum pidana dalam arti objektif sebagai :

1. Keseluruhan larangan dan perintah yang oleh negara diancam dengan nestapa yaitu suatu pidana apabila tidak ditaati;

2. Keseluruhan peraturan yang menetapkan syarat-syarat untuk penjatuhan pidana, dan;

3. Keseluruhan ketentuan yang memberikan dasar untuk penjatuhan dan penerapan pidana."3

Hukum pidana dalam arti subjektif atau ius puniendi bisa diartikan secara luas dan sempit, yaitu sebagai berikut : Dalam arti luas: Hak negara atau alat-alat perlengkapan negara untuk mengenakan atau mengancam pidana terhadap perbuatan tertentu dan dalam arti sempit: Hak untuk menuntut perkara-perkara pidana, menjatuhkan dan melaksanakan pidana terhadap orang yang melakukan perbuatan yang dilarang. Hak ini dilakukan oleh badan-badan peradilan. Jadi ius puniendi adalah hak untuk mengenakan pidana. Hukum pidana dalam arti subjektif (ius puniendi) yang merupakan peratuan yang mengatur hak negara dan alat perlengkapan negara untuk mengancam, menjatuhkan dan melaksanakan hukuman terhadap seseorang yang melanggar larangan dan perintah yang telah diatur di dalam hukum pidana dalam aeri objektif (ius poenale). Dengan kata lain, ius puniendi harus berdasarkan kepada ius poenale.

\section{B. Teori Evektifitas Hukum}

Kata efektif berasal dari bahasa Inggris yaitu effective yang berarti berhasil atau sesuatu yang dilakukan berhasil dengan baik. Kamus ilmiah populer mendefinisikan efetivitas sebagai ketepatan penggunaan, hasil guna atau menunjang tujuan. Menurut Kamus Besar Bahasa Indonesia, efektif adalah sesuatu yang ada efeknya (akibatnya, pengaruhnya, kesannya) sejak dimulai berlakunya suatu Undang-Undang atau peraturan, sedangkan efektivitas itu sendiri adalah keadaan dimana dia diperankan untuk memantau. ${ }^{4}$

Jika dilihat dari sudut hukum, yang dimaksud dengan "dia" disini adalah pihak yang berwenang yaitu polisi. Kata efektifitas sendiri berasal dari kata efektif, yang berarti terjadi efek atau akibat yang dikehendaki dalam suatu perbuatan. Setiap pekerjaan yang efisien berarti efektif karena dilihat dari segi hasil tujuan yang hendak dicapai atau dikehendaki dari perbuatan itu. Pada dasarnya efektivitas merupakan tingkat keberhasilan dalam pencapaian tujuan. Efektivitas adalah pengukuran dalam arti tercapainya sasaran atau tujuan yang telah ditentukan sebelumnya. Dalam sosiologi hukum, hukum memiliki fungsi sebagai a tool of social control

\footnotetext{
${ }^{3}$ P.A.F. Lamintang, 1984, Dasar-Dasar Hukum Pidana Idomesia, Sinar Baru, Bandung, hal.1-2

${ }^{4}$ Kamus Besar Bahasa Indonesia. 2002. Jakarta. Balai Pustaka. Hal. 284.
} 
yaitu upaya untuk mewujudkan kondisi seimbang di dalam masyarakat, yang bertujuan terciptanya suatu keadaan yang serasi antara stabilitas dan perubahan di dalam masyarakat. Selain itu hukum juga memiliki fungsi lain yaitu sebagai a tool of social engineering yang maksudnya adalah sebagai sarana pembaharuan dalam masyarakat. Hukum dapat berperan dalam mengubah pola pemikiran masyarakat dari pola pemikiran yang tradisional ke dalam pola pemikiran yang rasional atau modern. Efektivikasi hukum merupakan proses yang bertujuan agar supaya hukum berlaku efektif. Ketika kita ingin mengetahui sejauh mana efektivitas dari hukum, maka kita pertama-tama harus dapat mengukur sejauh mana hukum itu ditaati oleh sebagian besar target yang menjadi sasaran ketaatannya, kita akan mengatakan bahwa aturan hukum yang bersangkutan adalah efektif. Namun demikian, sekalipun dikatakan aturan yang ditaati itu efektif, tetapi kita tetap masih dapat mempertanyakan lebih jauh derajat efektivitasnya karena seseorang menaati atau tidak suatu aturan hukum tergantung pada kepentingannya. Sebagaimana yang telah diungkapkan sebelumnya, bahwa kepentingan itu ada bermacammacam, di antaranya yang bersifat compliance, identification, internalization. ${ }^{5}$

\section{Tinjauan Umum Makam}

Kata kuburan berasal dari kata dasar kubur, berasah dari bahasa arab, yang berarti memendam memasukan,melupakan mengebumikan Kata makam juga berarti tempat, tempat tinggal, kediaman. Kubur berasal dari bahasa arab adalah karta kerja yang berarti menanam atau memendam sesuatu biasanya jenazah seseorang atau bangkai hewan didalam tanah. Kuburan atau pekuburan adalah tempat dimana jenazah- jenazah dikuburkan juga disebut pemakaman.

Ada beberapa aturan yang terkait dengan kuburan yang dikemukakan para ahli fikih berdasarkan sunah Rasulullah SAW. Menguburkan mayat bertujuan agar tidak bauyang tidak sedap dari mayat. Lubang kubur harus luas panjang dalam dan lebar sesuai dengan sabda Rasullah SAW "Galilah kuburan lebarkan dan dalamkan(kuburan) itu"(HR at-Tirmizi).Dianjurkan untuk membuat lahad jika tanah kuburan keras yaitu lubang khusus di dinding samping lubang kubur ukuranya cukup untuk memiringkan mayat ke arah kiblat dalam dalam keadaan tidur. Posisi mayat munutur ulama Mazhab Syafi'i dan Hambali wajib di hadapkan ke kiblat alasanya karena RasulullahSAW sendiri ketika dikuburkan dihadapkan ke kiblat. Disunahkan bagi orang yang mengikuti jalannya pemakaman untuk ikut menimbun kuburan walaupun hanya

5 Achmad Ali. 2009. Menguak Teori Hukum (Legal Theory) dan Teori Peradilan (Judicialprudence) Termasuk Interpretasi Undang-Undang (Legisprudence). Jakarta.

Penerbit Kencana. Hal. 375. 
beberapa gumpal tanah. Mahkruh hukumnya membuat kuburan seperti bangunan menandai dengan tulisan .Alasanya adalah hadis Rasulluah SAW dari Jabri bin Abdullah yang menyatakan :"Rasullah melarang membangun kuburan menulis tulisan-tulisan di kuburan dan membuatnya seperti kubah masjid(HR.Muslim). Dilarang meletakkan alat penerangan sesuai dengan hadis berikut "Allah melaknat orang yahudiyang menjadikan kuburan sebagai tempat sujud dan memberikannya alat penerangan.

Para ahli fiqih telah sepakat bahwa memakamkan atau menguburkan jenazah hukumya adalah fardhu kifayah sebagaimana halnya memandikan, mengkafani dan menshalatkan.Kewajiban mengkuburkan ditetapkan berdasarkan al-qur'an berdasarkan surat al Mursalat ayat 25-26 " bukanlah kami menjadikan bumi ( tempat) berkumpul orang-orang hidup dan orang-orang mati.Selain iti dalam surat Abasa ayat 21 artinya " kemudian Dia mematikannya dan memasukannya kedalam kubur".

\section{Tinjauan Umum Covid-19}

Pada 31 Desember 2019, WHO China Country Offce melaporkan kasus pneumonia yang tidak diketahui etiologinya di Kota Wuhan, Provinsi Hubei, China. Pada tanggal 7 Januari 2020, China mengidentifkasi pneumonia yang tidak diketahui etiologinya tersebut sebagai jenis baru coronavirus (novel coronavirus). Pada awal tahun 2020 NCP mulai menjadi pendemi global dan menjadi masalah kesehatan di beberapa negara di luar RRC. Berdasarkan World Health Organization (WHO) kasus kluster pneumonia dengan etiologi yang tidak jelas di Kota Wuhan telah menjadi permasalahan kesehatan di seluruh dunia. Penyebaran epidemi ini terus berkembang hingga akhirnya diketahui bahwa penyebab kluster pneumonia ini adalah Novel Coronavirus. Pandemi ini terus berkembang hingga adanya laporan kematian dan kasuskasus baru di luar China. Pada tanggal 30 Januari 2020, WHO menetapkan COVID-19 sebagai Public Health Emergency of International Concern (PHEIC)/ Kedaruratan Kesehatan Masyarakat Yang Meresahkan Dunia (KKMMD)1 . Pada tanggal 12 Februari 2020, WHO resmi menetapkan penyakit novel coronavirus pada manusia ini dengan sebutan Coronavirus Disease (COVID-19). COVID-19 disebabkan oleh SARS-COV2 yang termasuk dalam keluarga besar coronavirus yang sama dengan penyebab SARS pada tahun 2003, hanya berbeda jenis virusnya. Gejalanya mirip dengan SARS, namun angka kematian SARS (9,6\%) lebih tinggi dibanding COVID-19 (saat ini kurang dari 5\%), walaupun jumlah kasus COVID-19 jauh lebih banyak dibanding SARS. COVID-19 juga memiliki penyebaran yang lebih luas dan cepat ke beberapa negara dibanding SARS. 
Corona virus jenis baru yang ditemukan pada manusia sejak kejadian luar biasa muncul di Wuhan China, pada Desember 2019, kemudian diberi nama Severe Acute Respiratory Syndrome Coronavirus 2 (SARS- COV2), dan menyebabkan penyakit Coronavirus Disease-2019 (COVID-19). COVID-19 termasuk dalam genus dengan for elliptic dan sering berbentuk pleomorfk, dan berdiameter 60-140 nm. Virus ini secara genetik sangat berbeda dari virus SARS-CoV dan MERS-CoV. Penelitian saat ini menunjukkan bahwa homologi antara COVID-19 dan memiliki karakteristik DNA coronavirus pada kelelawar-SARS yaitu dengan kemiripan lebih dari 85\%. Ketika dikultur pada vitro, COVID-19 dapatditemukandalamsel epitel pernapasan manusia setelah 96 jam. Sementara itu untuk mengisolasi dan mengkultur vero E6 dan Huh-7 garis sel dibutuhkan waktu sekitar 6 hari. Paru-paru adalah organ yang paling terpengaruh oleh COVID-19, karena virus mengakses sel inang melalui enzim ACE2, yang paling melimpah di sel alveolar tipe II paru-paru. Virus ini menggunakan glikoprotein permukaan khusus, yang disebut "spike", untuk terhubung ke ACE2 dan memasuki sel inang6 . Kepadatan ACE2 di setiap jaringan berkorelasi dengan tingkat keparahan penyakit di jaringan itu dan beberapa ahli berpedapat bahwa penurunan aktivitas ACE2 mungkin bersifat protektif. Dan seiring perkembangan penyakit alveolar, kegagalan pernapasan mungkin terjadi dan kematian mungkin terjadi

\section{METODE PENELITIAN}

Jenis penelitian adalah deskriftif analitis, yaitu untuk menggambarkan, menemukan fakta-fakta hukum secara menyeluruh dan mengkaji secara sistematis Terhadap Merintangi Penguburan Jenazah Covid-19 Ditinjau Berdasarkan Pasal 178 Kitab Undang-Undang Hukum Pidana.

\section{PEMBAHASAN}

Di beberapa daerah, warga menolak pemakaman korban positif Covid-19 di wilayah mereka. Alasannya, warga khawatir tertular virus mematikan itu. Namun penolakan itu dianggap berlebihan. Menghalanghalangi petugas yang akan melakukan pemakaman resmi secara hukum memang dapat dipidana. Aparat penegak hukum dapat menggunakan Pasal 178 KUHP. Meskipun demikian legalitas pasal ini adalah delik 
biasa, bukan delik aduan. Aparat penegak hukum dapat langsung melakukan tindakan tanpa ada yang mengadu.

"Jika kejadiannya memenuhi unsur-unsur yang ada dalam Pasal 178 KUHP, maka pelaku bisa saja dijerat. Tetapi, tetapi harus melihat pada niat dan perbuatan sebagai syarat untuk menjatuhkan pidana kepada seseorang. Pasal 178 KUHP menyatakan: "Barang siapa yang dengan sengaja merintangi atau menghalang-halangi jalan masuk atau pengangkutan mayat ke kuburan yang diizinkan. diancam dengan pidana penjara paling lama satu bulan dua minggu atau pidana denda paling banyak seribu delapan ratus rupiah".

Pasal ini berada di bawah bab mengenai kejahatan terhadap ketertiban umum. Rumusan ini ada padanannya dalam Nederland Wetboek van Strafrecht, yakni Pasal 148. Ancaman pidana ini ditujukan (normaddressat) kepada 'barang siapa', atau 'siapapun'. Bagian inti deliknya adalah 'sengaja', 'merintangi atau menghalang-halangi', dan 'jalan masuk atau pengangkutan mayat ke kuburan yang diizinkan'. Dalam buku KUHP, R. Soesilo mencatat perbuatan ini harus dilakukan dengan sengaja 'merintangi', artinya menghalang-halangi, sehingga pembawaan mayat itu tidak dapat berlangsung (verhideren). 'Menyusahkan' artinya mengganggu, sehingga meskipun pembawaan mayat itu dapat berlangsung, akan tetapi dengan susah payah (belemmeren). Selain itu dijelaskan Soesilo, pembawaan mayat itu harus tidak terlarang. Artinya pembawaan itu patut, diizinkan oleh aparat pemerintah. Bukan penguburan mayat secara gelap.

Kementerian Agama telah menerbitkan dua surat edaran protikol Pemakaman Covid- 19:

Surat Edaran Direktur Jenderal Bimbingan Masyarakat Islam Nomor P-002/DJ.III/HK.00.7/03/2020 Tahun 2020 tentang Imbauan dan Pelaksanaan Protokol Penanganan COVID-19 pada Area Publik di Lingkungan Direktorat Jenderal Bimbingan Masyarakat Islam ("SE Dirjen BIMAS Islam P-002/2020") sebagaimana yang telah diubah dengan Surat Edaran Direktur Jenderal Bimbingan Masyarakat Islam Nomor P003/DJ.III/HK.00.7/04/2020 Tahun 2020 tentang Perubahan atas Surat Edaran Direktur Jenderal Bimbingan Masyarakat Islam Nomor P002/DJ.III/HK.00.7/03/2020 Tahun 2020 tentang Pelaksanaan Protokol Penanganan COVID-19 pada Area Publik di Lingkungan Direktorat Jenderal Bimbingan Masyarakat Islam ("SE Dirjen BIMAS Islam P003/2020");

Surat Imbauan Direktur Jenderal Bimbingan Masyarakat Kristen Nomor B-512/DJ.IV/Dt.IV.I/BA.01.1/3/2020 Tahun 2020 tentang Pelayanan Pemberkatan Nikah dan Penguburan, terkait darurat COVID19 (“SE Dirjen BIMAS Kristen B-512/2020”). 
Bagian Keempat huruf a SE Dirjen BIMAS Islam P002/2020 jo. Bagian Kedua SE Dirjen BIMAS Islam P003/2020 menerangkan bahwa dalam pengurusan jenazah:

1. Pengurusan jenazah pasien COVID-19 dilakukan oleh petugas kesehatan yang beragama Islam dari pihak rumah sakit yang telah ditetapkan oleh Kementerian Kesehatan;

2. Jenazah ditutup dengan kain kafan/bahan dari plastik (tidak dapat tembus air). Dapat juga jenazah ditutup dengan bahan kayu atau bahan lain yang tidak mudah tercemar;

3. Jenazah yang dibungkus tidak boleh dibuka lagi, kecuali dalam keadaan mendesak, seperti autopsi dan hanya dapat dilakukan oleh petugas; dan

4. Jenazah disemayamkan tidak lebih dari empat jam.

Bagian Keempat huruf $b$ SE Dirjen BIMAS Islam P002/2020 kemudian menerangkan mengenai protokol pada salat jenazah:

1. Untuk pelaksanaan salat jenazah, dilakukan di rumah sakit rujukan. Jika tidak, salat jenazah dilakukan di masjid yang sudah dilakukan proses pemeriksaan sanitasi secara menyeluruh dan melakukan disinfektasi setelah salat jenazah;

2. Salat jenazah dilakukan sesegera mungkin dengan mempertimbangkan waktu yang telah ditentukan, yaitu tidak lebih dari empat jam;

3. Salat jenazah dapat dilaksanakan sekalipun oleh satu orang. Bagian Keempat huruf c SE Dirjen BIMAS Islam P-002/2020 jo.

Kedua SE Dirjen BIMAS Islam P-003/2020 kemudian menguraikan protokol dalam penguburan jenazah:

1. Jenazah harus dikubur pada kedalaman 1,5 meter, lalu ditutup dengan tanah setinggi satu meter;

2. Setelah semua prosedur jenazah dilaksanakan dengan baik, maka keluarga dapat turut dalam penguburan jenazah;

3. Penguburan beberapa jenazah dalam satu liang kubur diperbolehkan, karena darurat;

4. Setelah pengafanan selesai, jenazah dimasukkan ke dalam peti jenazah yang tidak tembus air dan udara dengan dimiringkan ke kanan. Dengan cara demikian, saat dikubur, jenazah menghadap kiblat;

5. Penguburan jenazah dengan cara memasukkannya ke dalam peti ke liang kubur dilakukan tanpa harus membuka peti, plastik, dan kain kafan;

6. Penguburan jenazah dapat dilaksanakan di tempat pemakaman umum.

Masyarakat tidak perlu khawatir sebab jenazah korban Covid-19 telah dilakukan sesuai protokol kesehatan. Jenazah korban Covid-19 dapat 
dimakamkan di pemakaman umum. Bagi warga yang menolak pemakaman di wilayahnya berarti itu tidak benar. Tidak boleh menolak pemakaman. Menghalangi-halangi saja tidak boleh. Perbuatan ini dapat dijerat sanksi hukum. Aparat penegak hukum dapat langsung melakukan tindakan tanpa ada yang mengadukan terlebih dahulu. Pasal 178 KUHP itu merupakan delik biasa bukan delik aduan. Delik biasa artinya delik yang dapat diproses tanpa adanya persetujuan dari yang dirugikan (keluarga jenazah Covid-19). Jadi tidak perlu ada aduan terlebih dahulu. Berbeda jika delik aduan, yang hanya bisa diproses apabila ada pengaduan atau laporan dari orang yang menjadi korban tindak pidana. Merintangi, menghalang-halangi, menyusahkan, mengganggu proses pemakaman jenazah korban Covid-19 atau mempersulit proses pemakaman dapat dipidana. Tidak boleh memiliki rasa khawatir berlebihan. Jenazah korban Covid-19 yang telah dimakamkan tidak akan menularkan virus Covid-19. Seyogianya tidak terjadi lagi penolakan pemakaman jenazah korban Covid-19 di negara Indonesia.

Berikut penulis akan merangkum beberapa faktor yang menyebabkan terjadinya perintangan penguburan Jenazah Covid - 19 :

1. Ada stigma yang berkembang terhadap penderita Covid-19 atau bahkan mereka yang berada di garis depan menangani pasien virus corona. Alasannya, khawatir menjadi sumber penyebaran virus corona. Hal ini pula yang menjadi faktor dari merintangi penguburan jenazah.

2. Penolakan karena kurangnya sosialisasi dan kepercayaan masyarakat yang tidak rasional, Sosiologi dari Universitas Indonesia (UI) Ida Ruwaida mengatakan, penolakan pemakaman jenazah COVID-19 yang terjadi di tengah masyarakat memang sangat disesali. Tapi, ujar dia, peristiwa ini terjadi bukan tanpa sebab. Menurut dia, akar masalah ini salah satunya bersumber dari sosialisasi yang tidak menjangkau hingga ke level bawah masyarakat. "Akar masalahnya bisa jadi memang sosialisasi yang kurang intens di level bawah, tapi yang jadi persoalan, masyarakat sudah punya belief yang kadang tidak rasional," 6

3. Penolakan jenazah lebih kepada perilaku kolektif, ada orang-orang yang menjadi provokator, penolakan jenazah lebih kepada perilaku kolektif, tentu akan ada orang-orang yang menjadi provokator untuk menggerakkan dan memengaruhi masyarakat agar tidak rasional. Sikap masyarakat Indonesia yang seperti ini, kata Ida, mencerminkan bahwa daya kritis masyarakat masih rendah. Kisah diskriminatif seperi ini pun bukan kali pertama terjadi. Ida mengingatkan bagaimana dulu pasien pengidap HIV/AIDs juga mengalami perlakuan yang sama, bahkan

6 https://kaltim.idntimes.com/news/indonesia/lia-hutasoit-1/marak-penolakan-jenazahcovid-19-masalah-hati-atau-kurang-edukasi-regional-kaltim/full, diakses pada tanggal 29 Mei 2020 
oleh tenaga medis. "Sementara kini, masih banyak anggota masyarakat yang juga kurang paham, tidak mau paham bahwa sehatnya tenaga medis merupakan isu mendasar bagi kita semua. Dalam masyarakat Indonesia yang berkultur reaktif, berkembang anggapan jika tidak mengalaminya sendiri tidak akan percaya atau belum yakin.

4. Hoax soal Virus Covid-19 yang merajalela di media sosial, masyarakat Indonesia mudah dirangsang dengan info-info yang kurang tepat, sehingga membat panik warga sekitar yang berdampak merintangi penguburan jenazah Covid-19. Selama masa pandemik virus corona ini saja, Kementerian Komunikasi dan Informasi telah mencatat lebih dari 1.096 hoaks muncul terkait virus corona. Angka ini membuktikan bahwa hoaks soal COVID-19 masih laris manis. "Hingga saat ini sudah ada total 1.096 isu hoaks terkait COVID-19 yang tersebar di platform Facebook, Instagram, Twitter, dan YouTube.

\section{PENUTUP}

\section{A. Kesimpulan}

1. Menghalang-halangi petugas yang akan melakukan pemakaman resmi secara hukum memang dapat dipidana. Aparat penegak hukum dapat menggunakan Pasal 178 KUHP. Meskipun demikian legalitas pasal ini adalah delik biasa, bukan delik aduan. Aparat penegak hukum dapat langsung melakukan tindakan tanpa ada yang mengadu. "Jika kejadiannya memenuhi unsur-unsur yang ada dalam Pasal 178 KUHP, maka pelaku bisa saja dijerat. Tetapi, tetapi harus melihat pada niat dan perbuatan sebagai syarat untuk menjatuhkan pidana kepada seseorang. Pasal 178 KUHP menyatakan: "Barang siapa yang dengan sengaja merintangi atau menghalang-halangi jalan masuk atau pengangkutan mayat ke kuburan yang diizinkan. diancam dengan pidana penjara paling lama satu bulan dua minggu atau pidana denda paling banyak seribu delapan ratus rupiah.

2. Faktor yang menyebabkan terjadinya perintangan penguburan Jenazah Covid - 19:

a. Ada stigma yang berkembang terhadap penderita Covid-19 atau bahkan mereka yang berada di garis depan menangani pasien virus corona. Alasannya, khawatir menjadi sumber penyebaran virus corona

b. Penolakan karena kurangnya sosialisasi dan kepercayaan masyarakat yang tidak rasional.

c. Penolakan jenazah lebih kepada perilaku kolektif, ada orang-orang yang menjadi provokator, penolakan jenazah lebih kepada 
perilaku kolektif, tentu akan ada orang-orang yang menjadi provokator untuk menggerakkan dan memengaruhi masyarakat agar tidak rasional.

d. Hoax soal Virus Covid-19 yang merajalela di media sosial, masyarakat Indonesia mudah dirangsang dengan info-info yang kurang tepat, sehingga membuat panik warga yang berakibat penolakan atau merintangi penguburan jenazah Covid-19.

\section{B. Saran}

1. Sosialisasi secara berkelanjutan tentang Covid 19 harus terus dilakukan dengan cara memberikan pengetahuan yang benar kepada seluruh masyarakat, sehingga tidak terjadi lagi tindakan yang tidak berperikemanusiaan terhadap para korban covid 19, apalagi korban tersebut adalah orang yang telah mengorbankan hidupnya untuk menyelamatkan nyawa orang lain.

2. Tindakan-tindakan yang tidak manusiawi malah akan semakin memperburuk situasi, orang akan takut untuk melaporkan dirinya ketika terpapar, hal tersebut akan sangat membahayakan bagi keselamatan kita bersama, mari kita tetap bijak dalam membuat suatu keputusan dalam upaya bersama memutus mata rantai penyebaran Corona virus disease (Covid 19).

3. Bagi aparat penegak hukum kiranya memberikan tindakan, shock therapy, karena ini delik umum polisi bisa mengambil tindakan ketika itu (kejadian). Kalau melawan aparat karena menolak dibubarkan bisa jadi unsur pidana baru. Dan Mengedukasi warga terkait penanganan Covid-19, khususnya soal pemakaman jenazah positif juga harus terus dilakukan.

\section{DAFTAR PUSTAKA}

\section{A. Buku}

Achmad Ali. 2009. Menguak Teori Hukum (Legal Theory) dan Teori Peradilan (Judicialprudence) Termasuk Interpretasi Undang-Undang (Legisprudence).

Kamus Besar Bahasa Indonesia. 2002. Jakarta. Balai Pustaka

P.A.F. Lamintang, 1984, Dasar-Dasar Hukum Pidana Idomesia, Sinar Baru, Bandung

Arifin, Y. N. 2016. Optimalisasi Usaha Penyediaan Lahan Pemakaman dalam Kawasan Perumahan di Kabupaten Boyolali. 


\section{B. Peraturan Perundang-Undangan}

Undang-Undang Dasar Negara Republik Indonesia Tahun 1945.

Kitab Undang-undang Hukum Pidana (KUHP)

Kitab Undang-undang Hukum Acara Pidana (KUHAP)

\section{Internet}

https://www.jurnaljambi.co/2020/04/13/pasca-penolakan-jenazahperawat-warga-sewakul-khawatir-tak-dapat-pelayanankesehatan/ diakses tanggal 26 April 2020

https://kaltim.idntimes.com/news/indonesia/lia-hutasoit-1/marakpenolakan-jenazah-covid-19-masalah-hati-atau-kurang-edukasiregional-kaltim/full, diakses pada tanggal 29 Mei 2020 